\begin{tabular}{|l|l|l||}
\hline \multicolumn{2}{|c|}{ PublisherInfo } \\
\hline \hline PublisherName & $:$ & BioMed Central \\
\hline \hline PublisherLocation & $:$ & London \\
\hline \hline PublisherImprintName & $:$ & BioMed Central \\
\hline \hline
\end{tabular}

\title{
Europe boosts post-genomic research
}

\begin{tabular}{|l|l|l||}
\hline \multicolumn{2}{|c|}{ ArticleInfo } \\
\hline \hline ArticleID & $:$ & 4431 \\
\hline \hline ArticleDOI & $:$ & $10.1186 /$ gb-spotlight-20020327-01 \\
\hline \hline ArticleCitationID & $:$ & spotlight-20020327-01 \\
\hline \hline ArticleSequenceNumber & $:$ & 97 \\
\hline \hline ArticleCategory & $:$ & Research news \\
\hline ArticleFirstPage & $:$ & 1 \\
\hline \hline ArticleLastPage & $:$ & 4 \\
\hline \hline & & RegistrationDate : 2002-3-27 \\
\hline ArticleHistory & $:$ & OnlineDate \\
\hline \hline ArticleCopyright & $:$ & BioMed Central Ltd2002-3-27 \\
\hline \hline ArticleGrants & $:$ & \\
\hline \hline ArticleContext & $:$ & 130593311 \\
\hline \hline
\end{tabular}




\section{Helen Gavaghan}

Email: gavers@supanet.com

LONDON - Post-genomic research received a boost this month when the European Union (EU) awarded -39.4 million (around $\$ 40$ million) to three pan-European projects intended to enhance Europe's scientific base for translating the fruits of the human genome project into medical discoveries. The size and organization of the projects are a marked departure from previous EU-funded research, and demonstrate how the EU intends to fund most science in future. Each project was selected because it needs international and multidisciplinary collaboration if it is to succeed.

The -39.4 million will be split roughly three ways between the consortia. One will focus on standardizing twin registers and developing research tools for linking twin genotypes and phenotypes. A second will develop standardized ways to characterize mutant mice, while a third will undertake a threedimensional structural analysis of some 600 human and pathogen proteins. The awards are for three years.

Leena Peltonen, a professor of molecular genetics at the Finnish National Public Health Institute in Helsinki will head the twin work. "It is a project we have dreamed about for a long time," says Marcus Perola, a genetic epidemiologist in Peltonen's group, "but it was too expensive to undertake with national funds or under previous EU funding rules." Then the group saw last year's invitation to tender for funds of up to -13 million for 'integrated projects', meaning research proposals that would work only if conducted at the European level. This level of funding is some six or seven times that traditionally awarded as an EU research grant.

With the award of about -13.4 million ( $£ 8.3$ million), the twin study will 'harmonize' six twin registers (from Finland, Sweden, Norway, Denmark, The Netherlands and Italy) containing the names of some 800,000 twins. Discussions are also under way to include twin registers from Germany, the UK and Belgium. The long-term aim is to ensure that the data in each are compatible for all registrants, so that studies linking genetic profiles to diseases with multiple genetic and environmental causes will have statistical power.

A number of the registers, for example the Finnish one, are also linked to other national databases, such as hospital discharge records. "One of the advantages Europe has," says Jacques Remacle, a scientific officer in the European commission's research directorate, "is access to centralized national health records that cover someone's whole life."

The group's first step will be to select 5000 people from the registers where there is information already recorded about coronary heart disease, migraine, longevity, height and weight. The group is interested in those twins where there is a common phenotype and those with very different phenotypes. From blood samples, the researchers will develop a genetic profile for each of some 90 markers. Where there are chromosomal regions in common, the finding will be compared with those from a population study known as Morgam, to see whether the finding holds true for non-twins. The initial element of the study is being undertaken because data already exist on the five traits selected, "but in future," says Pelora, "we will need to decide on priorities and which disease to target. I imagine they will be those with significant public health consequences, such as diabetes and asthma." 
While Peltonen's team tries to highlight specific genetic and environmental contributors to complex disease, a consortium of European groups headed by Steve Brown, of the Medical Research Council's Mammalian Genetics Unit in Harwell, and Pierre Chambon, from the Institute of Genetics and Molecular Cell Biology at the University of Strasbourg, want to harmonise the way that mutant mice are characterized. The consortium's award is for -12.3 million ( $£ 7.6$ million).

There are a lot of mutant mice in European research institutes, some deliberately bred to have genetic susceptibility to disease (directed mutagenesis), and some in which random mutations have arisen. Knowing which phenotype is associated with which mutation can contribute to understanding the genetic basis of disease in humans because there is some $95 \%$ commonality between the mouse and human genomes. The idea, says Remacle, is to get a clear picture of the phenotypes of all mutant mice in Europe, which means developing standard tests for blood, brain and other body organs. The project will also develop new methods for directed mutagenesis as well as bioinformatics tools for exploring the links between phenotype and genotype.

The third project, with an award of -13.7 million ( $£ 8.45$ million), will determine the three-dimensional structure of proteins. The consortium, headed by David Stuart from the University of Oxford and Dino Moras, from the University of Strasbourg, intends to find ways to speed up each of the steps of structural analysis from protein production and purification to crystallizing the protein. Efforts will be made, too, to find ways to speed up the application of NMR and X-ray crystallography to structural analysis. The project will focus on proteins known to be involved in cancer and neurodegenerative disorders and on proteins found in a number of pathogens, including herpes virus and Mycobacter tuberculosis. In the first year, the structure of some 30 human and 30 pathogen proteins will be determined.

Besides their scientific significance, these projects and their organization are important because they demonstrate to the life-science community the type of research proposals that will find favor in the next EU research plan. Known as Framework 6, this plan currently has -2.2 billion earmarked for genomic research for human health.

In the past, the EU has released detailed, quite prescriptive research goals, and awards have been in the order of thousands to hundreds of thousands of pounds, not millions. As part of a strategy to develop a European Research Area, Framework 6 names seven broad themes across all areas of science and says that a substantial portion of the budget will be spent on large projects that are generated by the scientists, not the bureaucracy, and that need pan-European co-operation to succeed.

As yet, the European parliament and ministers have not decided exactly how much of the -2.2 billion dedicated to the genomics theme (one of the seven) will be spent on the large projects and how much on more traditional grants, but informed sources guess the split will be a 70:30 ratio of big projects to small projects. The large projects might be similar to those awarded for the twin, mouse and protein structure work (called 'integrated projects' in 'Eurospeak'), or they might be so-called 'networks of excellence'. Last week, the EU invited expressions of interest by 7 June of this year from consortia interested in either. 


\section{References}

1. Finnish National Public Health Institute, [http://www.ktl.fi/index.en.html]

2. MRC Mammalian Genetics, [http://www.mgu.har.mrc.ac.uk/]

3. University of Oxford, [http://www.ox.ac.uk/]

4. Sixth European Framework Programme - a translation. BioMed Central 5 April 2001., [http://www.the-scientist.com/news/20010405/03]

5. Invitation to submit expressions of interest, [http://www.cordis.lu/fp6/eoi-instruments/] 